\title{
Determining the Attachment Styles of Football Coaches to Their Athletes
}

\author{
Recep Fatih Kayhan (Corresponding author) \\ School of Physical Education and Sports \\ Recep Tayyip Erdogan University, Rize, Turkey \\ Tel: 90-506-446-8009 E-mail: recepfatih.kayhan@erdogan.edu.tr
}

$\begin{array}{ll}\text { Received: September 9, } 2020 & \text { Accepted: October 12, } 2020 \quad \text { Published: October 26, } 2020 \\ \text { doi:10.5296/jei.v6i2.17668 } & \text { URL: https://doi.org/10.5296/jei.v6i2.17668 }\end{array}$

\begin{abstract}
In this study, it was aimed to determine the attachment styles of soccer trainers to their athletes according to various variables. The relationship between the trainers and their athletes is an important element to act in line with the goals, in this context, determining the attachment styles will create an awareness for the trainers and will provide support for the development of the trainers in order to raise successful and mentally healthy athletes in the long term. The research sample consists of 406 licensed male football coaches who are actively performing as trainers in football at different levels and age groups. In the study, a questionnaire was created using the trainer-athlete attachment scale to determine the personal information form attachment styles to collect the demographic characteristics of football coaches. SPSS 25 program was used to analyze the data. It was determined that the data were distributed normally, and the t-test and the One-way ANOVA test was used to compare independent groups. Tukey test was used as a complementary post-hoc analysis to determine the difference after the ANOVA test. The significance level in the analyses was determined to be $p<0.05$. While there was a significant difference in attachment styles of the trainers according to marital status, number of weekly training and years of coaching; no significant difference was found according to the variables of age, education level and coaching level. As a result, it was found that coaches who are married and train 6 times and more in a week have good problem-solving skills in their interpersonal relationships, have a positive approach to problems, are constructive while solving problems, are self-confident, do not evade responsibility, and have an insistent attitude in solving problems. Trainers can help athletes develop their positive emotions and life satisfaction with healthy evaluations and positive/optimistic thoughts. It is thought that the sharing environment that develops as a result of the cooperation and efforts made in line with common goals in sports environments, especially in training, increases the level of coach-athlete relationship.
\end{abstract}


Keywords: Coach, Athlete, Football, Attachment styles

\section{Introduction}

As a result of the relationships that children create with their families in their lives, an emotional rapprochement emerges between their families and themselves (Ainsworth, 1967). Bowlby defined this rapprochement as attachment (Bowlby, 1973, 1980). Bowlby (1980, 1982) defined attachment as a strong desire to establish a relationship or intimacy with a figure when an individual feel scared, tired, or sick. The basic element of attachment is that a human being born in a way that cannot execute his life cannot survive without the care of an adult (Karakuş, 2012).

According to the studies conducted, it has been observed that individuals with a secure attachment style have good problem-solving skills in their interpersonal communication, react positively to problems, are constructive in solving problems, have a high feeling of trust, are responsible and persistent in problem solving (Baysal \& Özgenel, 2019; Demir, 2019; Yiğit, 2020; Koser \& Barut, 2020). Considering that attachment styles are effective in relationships with adult individuals, first caregivers should approach babies and others with a positive attitude and show supportive attitudes towards their development, starting from early childhood. In line with this information, the quality of the relationships with children and adolescents and the place in the child's positive personality development should be explained and imposed to the mother or first caregivers. Trainings on the subject should be given especially to parents, teachers and educators, and studies should be put forward to develop their positive opinions (Arslan et al., 2012).

People have to continue their life cycle and live together because they are social personalities. People carry out their relationships in society in a certain order, in line with norm values, by cooperating in cooperation. It is a social phenomenon in sports and individuals to perform their physical activities in a joint activity within the framework of determined rules. They can take their place in this field not only by practicing one-to-one, but also by watching sports. It includes a philosophy that aims to develop the human mind in harmony with sports, friendship, brotherhood, achieving better and better, religion, language, and political view regardless of race (Zengin, 2019).

Training and development of athletes and sportspeople is important in this context. People can improve their physical condition with effective and correct study programs in the light of their innate abilities and their behaviors acquired later. It is seen in this process that individuals acquire different physical behaviors in line with their goals. Individuals involved in sports activities try to maximize their performance for their purposes or to keep their existing performances under control. While the physical abilities of athletes are taken into consideration in their performances, on the other hand, psychological conditions, which are effective in maximizing the existing physical performance, should not be ignored (Abakay, 2010).

It is revealed that the trainings given in the field of sports should focus on not only the muscles, but also the emotion and thinking structure, which are human characteristics 
(Ürkmez, 2008).

The quality of the coach-athlete relationship plays an important role in the development of the athlete both as an athlete and as an individual. Studies show that coaches have an effective role in athlete's self-esteem and well-being (Côté \& Fraser Thomas, 2007).

The fact that the coach-athlete relationship, which has an important place in increasing the performance of athletes, is among the important issues today, especially in our country, due to the insufficient number of studies in this field, the aim of revealing important information about the levels of coach-athlete relations as a result of these studies directs the studies. While it is thought that the observation and perception of the behavior of the trainer by the athlete has an effect on the performance of the athletes, the trainer effect is expected to be more efficient in order to achieve success in line with the goals (Altıntaş et al., 2012). In the sports environment, the relationship of the coach with the athlete is important for the psychosocial and physical development of the athlete (Jowett \& Cockerill, 2003).

Davis and Jowett (2010) stated that athletes adopt and perceive their trainers as a safe base, a safe area and a goal in terms of proximity in order to demonstrate three basic attachment abilities. They found the relationship between insecure attachment styles of athletes and trainer-athlete satisfaction. An important attachment figure of the coach for athletes they found that he described him as an experienced person who can consult him in situations requiring assistance, who helps him to understand and explore the sports environments around him, and as a reliable person who forms the basis for understanding sports (Davis \& Jowett, 2010).

With this study, it is important to explain the attachment theory, which is the basis of the relationships between individuals in the field of sports, and to reveal the level of coach-athlete attachment styles of football trainers. The fact that there are few studies on this subject in the national and international literature makes the current research unique. The determination of attachment styles will create awareness for the athlete and trainer and will provide support in raising successful and mentally healthy athletes and trainers in the long term.

Based on this information, it was aimed to determine the attachment styles of football trainers to their athletes according to various variables in line with the importance of the subject.

\section{Method}

\subsection{Research Group}

The research sample consists of 406 licensed male football coaches who are actively performing as trainers in football at different levels and age groups. The data of 19 people in total were not included in this study because 6 people did not have a football coach license, 8 were female trainers, and 5 were coaches, but did not work actively. Demographic data of the research group are shown in Table 1. 


\subsection{Collection of Data}

This study was conducted with the general survey model, which is one of the descriptive research methods, as the examination model. Screening model is the collection of information on any specified subject and again in order to determine the qualifications of a specified community. Many different questionnaire styles are applied to determine the opinions of the people through the questions asked to collect this information. These types of applications are applied to many individuals as possible as by phone, e-mail or directly asking them. Feedbacks given by the participants in the study are generally tabulated and reported in statistical data in the form of individual density levels and percentages (Büyüköztürk et al., 2012).

Participants were reached with the help of football coaches associations. The survey applications were made by responding to the Google survey file on the message application sent by phone. An explanation, indicating the aims and objectives of the research, was made at the introduction of the questionnaire application.

In the study, a questionnaire was created using the "Personal Information Form" and "Trainer-Athlete Attachment Scale" to collect information about football coaches.

\subsection{Data Collection Tool}

As a data collection tool, the Trainer-Athlete Attachment Scale developed by Davis and Jowett (2013) and adapted into Turkish by Zengin (2019) was used in line with the attachment theory. The Coach-Athlete Attachment Scale consists of 3 sub-dimensions (Safe, Anxious, Avoiding) and 19 items. In the items of the scale, the first 7 items assess the sub-dimensions of anxious attachment, 8-14 assess avoidant attachment, and 15-19 assess secure attachment styles. Scoring is performed according to 7-point Likert scale ranging from 1 (strongly disagree) to 7 (totally agree). Reliability coefficients of participants attachment and sub-dimensions; It was found that it had a reliability at avoidant attachment (0.775), anxious attachment $(0.861)$, secure attachment $(0.830)$, and total attachment $(0.775)$. The reliability coefficient varies between 0.775 and 0.861 . The reliability coefficients of the original scale three-dimensional trainer sub-dimensions have avoidant attachment (0.82), anxious attachment $(0.83)$ and secure attachment $(0.75)$ reliability.

\subsection{Data Analysis}

SPSS 25 program was used for data analysis. It was determined that the data were distributed normally (Tabachnick \& Fidell, 2013) and the t-test from the parametric tests was used to compare the quantitative continuous data between two independent groups, and the One-way Anova test was used to compare the quantitative continuous data among more than two independent groups. After the Anova test, Tukey test was used as a complementary post-hoc analysis to determine the differences. The level of significance in the analyses was determined to be $\mathrm{p}<0.05$. 


\section{Results}

Table 1. Distribution of the participants by demographic variables

\begin{tabular}{|c|c|c|c|}
\hline Variable & Group & $\mathbf{N}$ & $\%$ \\
\hline \multirow{4}{*}{ Age } & $20-30$ age & 58 & 14.3 \\
\hline & $31-40$ age & 134 & 33.0 \\
\hline & $41-50$ age & 144 & 35.5 \\
\hline & 51 age and more & 70 & 17.2 \\
\hline \multirow{2}{*}{ Marital status } & Single & 119 & 29.3 \\
\hline & Married & 287 & 70.7 \\
\hline \multirow{2}{*}{ Coaching Level } & Amateur & 242 & 59.6 \\
\hline & Professional & 164 & 40.4 \\
\hline \multirow{4}{*}{ Education Status } & High school & 100 & 24.6 \\
\hline & Undergraduate & 24 & 5.9 \\
\hline & License & 207 & 51.0 \\
\hline & Postgraduate & 75 & 18.5 \\
\hline \multirow{4}{*}{ Coaching Duration } & $1-5$ year & 99 & 24.4 \\
\hline & 6-10 year & 129 & 31.8 \\
\hline & $11-15$ year & 72 & 17.7 \\
\hline & 16 and more & 106 & 26.1 \\
\hline \multirow{3}{*}{ Number of Training per Week } & 1-3 Training & 102 & 25.1 \\
\hline & 4-5 Training & 211 & 52.0 \\
\hline & 6 Training and more & 93 & 22.9 \\
\hline
\end{tabular}

When Table 1, where demographic characteristics are summarized, is examined, it is seen that the number of participants is 406 in total, the age range of the participants in the study is in the 41-50 age range and the density of the participants in the study between the ages of 20-30 is very low. When we look at the marital status, there are $287(70.7 \%)$ married participants and 119 (29.3\%) single participants. As for the coaching levels of the participants, 242 of them (59.6\%) are amateur and 164 (40.4) are professional. When we look at the educational status of the participants, it is seen that 100 of them $(24.6 \%)$ graduated from high school, 24 (5.9\%) have an associate degree, 207 (51.0\%) are undergraduate, and 75 (18.5\%) 
are graduates. According to the duration of the coaching period, 227 (75.7\%) people who have been coaching for 6-10 years constitute the highest group. According to the number of weekly training sessions, the group that performs 4-5 trainings per week (52.0\%) appears to be the highest with 211 participants.

Table 2. Trainer-athlete attachment scale sub-dimension levels in terms of marital status of the participants

\begin{tabular}{|c|c|c|c|c|c|c|c|}
\hline Variable & Marital status & $\mathbf{N}$ & Mean & Ss & df & $\mathbf{t}$ & $\mathbf{P}$ \\
\hline \multirow{2}{*}{ Avoidant attachment } & Single & 119 & 4.46 & 1.385 & \multirow{2}{*}{404} & \multirow{2}{*}{2.506} & \multirow{2}{*}{$0.01 *$} \\
\hline & Married & 287 & 4.05 & 1.533 & & & \\
\hline \multirow{2}{*}{ Anxious attachment } & Single & 119 & 2.60 & 1.360 & \multirow{2}{*}{404} & \multirow{2}{*}{2.174} & \multirow{2}{*}{$0.03 *$} \\
\hline & Married & 287 & 2.30 & 1.221 & & & \\
\hline \multirow{2}{*}{ Secure attachment } & Single & 119 & 6.06 & 0.889 & \multirow{2}{*}{404} & \multirow{2}{*}{0.974} & \multirow{2}{*}{0.33} \\
\hline & Married & 287 & 5.95 & 1.047 & & & \\
\hline
\end{tabular}

According to the marital status of the participants, the sub-dimension levels of the trainer-athlete attachment scale were tested using the t-test. According to the tests performed, there was a significant difference in both avoidant attachment $(\mathrm{t}(404)=2.506 ; \mathrm{p}<0.05)$ and anxious attachment levels in terms of marital status of the participants $(\mathrm{t}(404)=2.174 ; \mathrm{p}<$ 0.05). There was no significant difference in secure attachment sub-dimension levels $(\mathrm{p}>$ 0.05). In avoided attachment sub-dimension levels, the mean of single participants ( $\mathrm{X}=$ $4.46 \pm 1.38)$ is significantly higher than the mean of married participants $(X=4.05 \pm 1.53)$. In the anxiety attachment sub-dimension levels, the mean of single participants $(X=2.60 \pm 1.36)$ is significantly higher than the mean of married participants $(X=2.30 \pm 1.22)$.

Table 3. Trainer-athlete attachment scale sub-dimension levels of participants in terms of level of coaching

\begin{tabular}{|c|c|c|c|c|c|c|c|}
\hline Variable & Coaching Level & $\mathbf{N}$ & Mean & Ss & df & $\mathbf{t}$ & $\mathbf{p}$ \\
\hline \multirow{2}{*}{ Avoidant attachment } & Amateur & 242 & 4.17 & 1.459 & \multirow{2}{*}{404} & \multirow{2}{*}{-0.122} & \multirow{2}{*}{0.90} \\
\hline & Professional & 164 & 4.18 & 1.566 & & & \\
\hline \multirow{2}{*}{ Anxious attachment } & Amateur & 242 & 2.42 & 1.241 & \multirow{2}{*}{404} & \multirow{2}{*}{0.502} & \multirow{2}{*}{0.61} \\
\hline & Professional & 164 & 2.35 & 1.313 & & & \\
\hline \multirow{2}{*}{ Secure attachment } & Amateur & 242 & 6.02 & 1.050 & \multirow{2}{*}{404} & \multirow{2}{*}{0.948} & \multirow{2}{*}{0.34} \\
\hline & Professional & 164 & 5.92 & 0.930 & & & \\
\hline
\end{tabular}




\section{Al Macrothink}

The sub-dimension levels of the trainer-athlete attachment scale were tested using the t-test according to the training levels of the participants. According to the tests, no significant difference was found in the sub-dimension levels of the participants in terms of their coaching levels $(\mathrm{p}>0.05)$. In the anxious attachment and secure attachment sub-dimensions, it was observed that the mean score of the participants who are coaching at the amateur level is higher than that of the professional-level coaches, while in the avoidant attachment sub-dimension, the mean score of the participants who are coaching at the professional level is higher than that of the participants who are coaching at the amateur level.

Table 4. The trainer-athlete attachment scale sub-dimension levels in terms of age of the participants

\begin{tabular}{|c|c|c|c|c|c|c|c|}
\hline Variable & Age & $\mathbf{N}$ & Mean & Std. Deviation & Sd & $\mathbf{F}$ & $\mathbf{p}$ \\
\hline \multirow{4}{*}{ Avoidant attachment } & $20-30$ age & 58 & 4.27 & 1.057 & \multirow{4}{*}{$3-405$} & \multirow{4}{*}{1.229} & \multirow{4}{*}{0.29} \\
\hline & $31-40$ age & 134 & 4.31 & 1.564 & & & \\
\hline & $41-50$ age & 144 & 3.98 & 1.573 & & & \\
\hline & 51 age and older & 70 & 4.23 & 1.530 & & & \\
\hline \multirow{4}{*}{ Anxious attachment } & $20-30$ age & 58 & 2.54 & 1.126 & \multirow{4}{*}{$3-405$} & \multirow{4}{*}{0.362} & \multirow{4}{*}{0.78} \\
\hline & $31-40$ age & 134 & 2.34 & 1.211 & & & \\
\hline & $41-50$ age & 144 & 2.36 & 1.306 & & & \\
\hline & 51 age and older & 70 & 2.42 & 1.421 & & & \\
\hline \multirow{4}{*}{ Secure attachment } & $20-30$ age & 58 & 6.04 & 0.853 & \multirow{4}{*}{$3-405$} & \multirow{4}{*}{0.259} & \multirow{4}{*}{0.85} \\
\hline & $31-40$ age & 134 & 6.00 & 0.963 & & & \\
\hline & $41-50$ age & 144 & 5.98 & 1.047 & & & \\
\hline & 51 age and more & 70 & 5.89 & 1.113 & & & \\
\hline
\end{tabular}

The trainer-athlete attachment scale sub-dimension levels were tested using the ANOVA test according to the age of the participants. According to the tests, no significant difference was found in the trainer-athlete attachment scale sub-dimension levels in terms of the ages of the participants $(p>0.05)$. In the anxious attachment and secure attachment sub-dimensions, the mean score of the participants between the ages of 20-30 is higher, while the mean score of the participants between the ages of 31-40 in the avoiding attachment sub-dimension is higher. 
Table 5. Trainer-athlete attachment scale sub-dimension levels in terms of educational status of the participants

\begin{tabular}{|c|c|c|c|c|c|c|c|}
\hline Variable & Education Status & $\mathbf{N}$ & Mean & Std. Deviation & Sd & $\mathbf{F}$ & $\mathbf{p}$ \\
\hline \multirow{4}{*}{ Avoidant attachment } & High school & 100 & 4.16 & 1.650 & \multirow{4}{*}{$3-405$} & \multirow{4}{*}{0.794} & \multirow{4}{*}{0.49} \\
\hline & Undergraduate & 24 & 4.02 & 1.207 & & & \\
\hline & License & 207 & 4.12 & 1.430 & & & \\
\hline & Postgraduate & 75 & 4.41 & 1.573 & & & \\
\hline \multirow{4}{*}{ Anxious attachment } & High school & 100 & 2.34 & 1.437 & \multirow{4}{*}{$3-405$} & \multirow{4}{*}{1.362} & \multirow{4}{*}{0.25} \\
\hline & Undergraduate & 24 & 2.63 & 0.944 & & & \\
\hline & License & 207 & 2.31 & 1.070 & & & \\
\hline & Postgraduate & 75 & 2.61 & 1.581 & & & \\
\hline \multirow{4}{*}{ Secure attachment } & High school & 100 & 6.14 & 1.108 & \multirow{4}{*}{$3-405$} & \multirow{4}{*}{1.112} & \multirow{4}{*}{0.34} \\
\hline & Undergraduate & 24 & 5.93 & 1.262 & & & \\
\hline & License & 207 & 5.94 & 0.938 & & & \\
\hline & Postgraduate & 75 & 5.91 & 0.939 & & & \\
\hline
\end{tabular}

The sub-dimension levels of the trainer-athlete attachment scale were tested using the ANOVA test according to the educational status of the participants. According to the tests, no significant difference was found in the sub-dimension levels of the trainer-athlete attachment scale in terms of the educational status of the participants $(p>0.05)$. It was observed that the mean scores of the participants who received a master's degree, an associate's degree, and a high school education are higher in the sub-dimensions of avoided attachment, e anxious attachment, and secure attachment, respectively. 


\section{Macrothink}

Table 6. The trainer-athlete attachment scale sub-dimension levels of the participants in terms of their coaching year

\begin{tabular}{|c|c|c|c|c|c|c|c|c|}
\hline Variable & Coaching Duration & $\mathbf{N}$ & Mean & Std. Deviation & Sd & $\mathbf{F}$ & $\mathbf{p}$ & Difference \\
\hline \multirow{4}{*}{ Avoidant attachment } & $1-5$ year & 99 & 4.41 & 1.321 & \multirow{4}{*}{$3-405$} & \multirow{4}{*}{2.942} & \multirow{4}{*}{$0.03 *$} & \multirow{4}{*}{$\begin{array}{l}1>2 \\
1>3 \\
4>2\end{array}$} \\
\hline & $6-10$ year & 129 & 3.96 & 1.547 & & & & \\
\hline & $11-15$ year & 72 & 3.94 & 1.458 & & & & \\
\hline & 16 years and more & 106 & 4.38 & 1.588 & & & & \\
\hline \multirow{4}{*}{ Anxious attachment } & $1-5$ year & 99 & 2.67 & 1.255 & \multirow{4}{*}{$3-405$} & \multirow{4}{*}{3.279} & \multirow{4}{*}{$0.02 *$} & \multirow{4}{*}{$1>2$} \\
\hline & $6-10$ year & 129 & 2.17 & 0.938 & & & & \\
\hline & $11-15$ year & 72 & 2.29 & 1.536 & & & & \\
\hline & 16 years and more & 106 & 2.46 & 1.389 & & & & \\
\hline \multirow{4}{*}{ Secure attachment } & $1-5$ year & 99 & 5.91 & 0.982 & \multirow{4}{*}{$3-405$} & \multirow{4}{*}{0.230} & \multirow{4}{*}{0.87} & \\
\hline & $6-10$ year & 129 & 6.00 & 0.988 & & & & \\
\hline & $11-15$ year & 72 & 5.99 & 1.196 & & & & \\
\hline & 16 years and more & 106 & 6.02 & 0.906 & & & & \\
\hline
\end{tabular}

The sub-dimension levels of the trainer-athlete attachment scale were tested using the ANOVA test according to the coaching year of the participants. According to the tests, a significant difference was found in the avoidant attachment sub-dimension level (F (3.405) $=$ $2.942 ; \mathrm{p}<0.05)$ and anxious attachment sub-dimension level $(\mathrm{F}(3.405)=3.279 ; \mathrm{p}<0.05)$ in terms of duration of coaching. There was no significant difference in secure attachment sub-dimension level $(\mathrm{p}>0.05)$. Tukey Test was used as a second level test to determine among which groups the difference was found. When the averages are examined, the mean score of the participants who have been coaching for $1-5$ years $(X=2.67 \pm 1.25)$ regarding the anxious attachment sub-dimension is significantly higher than the mean of the participants who have been coaching for 6-10 years $(X=2.17 \pm 0.93)$. 
Table 7. Trainers-athletes attachment scale sub-dimension levels in terms of weekly training number of participants

\begin{tabular}{|c|c|c|c|c|c|c|c|c|}
\hline Variable & $\begin{array}{l}\text { Number of Training } \\
\text { per Week }\end{array}$ & $\mathbf{N}$ & Mean & Std. Deviation & Sd & $\mathbf{F}$ & $\mathbf{p}$ & Fark \\
\hline \multirow{3}{*}{ Avoidant attachment } & 1-3 Training & 102 & 4.12 & 1.541 & \multirow{3}{*}{$2-405$} & \multirow{3}{*}{1.902} & \multirow{3}{*}{1.15} & \\
\hline & 4-5 Training & 211 & 4.08 & 1.439 & & & & \\
\hline & 6 Training and above & 93 & 4.44 & 1.581 & & & & \\
\hline \multirow{3}{*}{ Anxious attachment } & 1-3 Training & 102 & 2.66 & 1.343 & \multirow{3}{*}{$2-405$} & \multirow{3}{*}{3.543} & \multirow{3}{*}{$0.03 *$} & \multirow{3}{*}{$1>3$} \\
\hline & 4-5 Training & 211 & 2.34 & 1.226 & & & & \\
\hline & 6 Training and above & 93 & 2.21 & 1.248 & & & & \\
\hline \multirow{3}{*}{ Secure attachment } & 1-3 Training & 102 & 5.87 & 1.126 & \multirow{3}{*}{$2-405$} & \multirow{3}{*}{0.930} & \multirow{3}{*}{0.39} & \\
\hline & 4-5 Training & 211 & 6.03 & 0.988 & & & & \\
\hline & 6 Training and more & 93 & 6.00 & 0.891 & & & & \\
\hline
\end{tabular}

According to the weekly training numbers of the participants, the sub-dimension levels of the trainer-athlete attachment scale were tested using the ANOVA test. According to the tests, a significant difference was found in the anxious attachment sub-dimension level (F (2.405) $=$ $3.543 ; \mathrm{p}<0.05)$ in terms of the number of weekly training of the participants, while no significant difference was found in the avoidant attachment and secure attachment sub-dimension levels ( $p>0.05$ ). Tukey Test was used as a second level test to determine among which groups the difference was found. When the averages are examined, it is seen that the anxious attachment sub-dimension averages of the participants who train 1-3 times per week $(X=2.66 \pm 1.34)$ are significantly higher than the averages of the participants who train 6 times and more per week $(X=2.21 \pm 1.24)$.

\section{Discussion}

It is thought that the determination of psychosocial levels such as effective communication between the coach and the athlete, feeling of trust and attachment style, which affect the performance of athletes, may be the key to success. In Turkish literature, coach-athlete/sportsman-binding was observed in a study that determines the style of relations manager. Considering that a healthy coach-athlete relationship is one of the important criteria for success in sports, it is expected that the current study will contribute to new studies in this field by revealing the relationship between coaches and athlete.

Significant differences were observed in the avoidant attachment and anxious attachment sub-dimensions according to the marital status of the participants. This finding indicates that the average score of single coaches is higher than that of married participants and that single coaches lack self-confidence towards their athletes, have difficulty in establishing closeness, 
and have negative feelings. The low average score of married participants in the anxious attachment dimension shows that they do not show an exaggerated interest in their spouses and the other person. It can be said that they smooth their attitude towards anxious attachment in the family environment. An avoiding attached trainer will perceive a low level of satisfaction with his athlete and this perception that his expectations are not being met has an impact on feelings of well-being. Studies have shown that coaches using behaviors that support autonomy can create an environment in which athletes feel that their psychological needs are met (Mageau \& Vallerand, 2003; Reinboth et al., 2004). On the other hand, a trainer using controlling behaviors is more likely to have athletes whose psychological needs are not met (Bartholomew et al., 2010; Blanchard et al., 2009).

There was no significant difference in sub-dimensions according to the coaching levels of the participants. The fact that the participants who train amateurly have a higher average score in the anxious attachment dimension than that of those who coach professionally show that they have more anxiety and negative emotions. It can be thought that this is because they are under pressure to be successful or to protect the position where they are. The fact that the scores of the professional and amateur coaching participants are close to each other in the avoidant attachment dimension shows that they have difficulty in establishing closeness and they hesitate to get support. It can be thought that the reason for this is due to the situation of the trainers participating in the study. It is thought that the constant change of the teams that Turkish coaches are in may create negative emotions such as low self-confidence, inability to establish closeness, insecurity, and being under stress. Fear of rejection or abandonment may arise in athletes due to the coaches' inability to maintain safe and close ties with their athletes. Studies have shown that high attachment anxiety leads to a contradictory situation during communication, causes anxiety and insecurity, but individuals with a high attachment avoidance tendency tend to avoid interaction and therefore cannot establish interpersonal relationships (Chen et al., 2017; Mallinckrodt \& Wei, 2005). It has been observed that coaches with secure attachment have higher self-esteem in their relationships with their athletes (Lee \& Hankin, 2009; Verschueren, 2020).

There was no significant difference in the subscale scores of the participants according to their ages. It is seen that the average score in the dimension of anxious attachment is higher in younger ages. It was observed that the average scores increased in the 51 and over age category, where mean scores were low in middle ages. It can be said that cognitive abilities of young trainers are affected by anxiety and this reflects this to their athletes. It can be thought that the reason for this is that the anxiety of the young and middle-aged coaches is caused by the future anxieties and that the anxiety of the future causes the fluctuating feelings. It is seen that the average scores are close to each other in the dimension of avoided attachment. It is observed that the trainers participating in the study have difficulty in establishing bonds with their athletes, they are reluctant to get support, and they have low self-confidence. In the secure attachment dimension, it is seen that the average scores decrease as the age gets older. It can be said that the sense of trust between the trainers participating in the study and their athletes decreases as the age gets older. Young coaches are thought to establish positive, optimistic, trusting and healthy relationships with their athletes. Coaches with an anxious 
attachment style do not expect support from their relatives, whereas individuals with an anxious attachment style have expectations of support (Ainsworth et al., 1978; Bowlby, 1973). For this reason, the trainer who avoids connecting can be expected to be more sensitive to the athlete as he/she does not have any expectations (Davis \& Jowett, 2011). In contrast, support attempts may not be felt less intimate or possibly well enough by coaches due to inconsistent support experiences of anxiously attached coaches. Supporting an avoidant attachment trainer can help improve perceptions of meeting basic needs in the coach-athlete relational context. Although there is no study in the literature that examines the coach-athlete relationship in terms of the age of the trainers, different studies examining the coach-athlete relationship have examined athletes in terms of their ages and it was found that more experienced athletes perceive more authoritarian behavior than their trainers. In addition, less experienced athletes perceive more positive feedback. Younger athletes perceive more closeness than their coaches (Y1ldırım et al., 2019).

There was no difference in the sub-dimension scores according to the education level of the participants. According to the educational status variable, the attachment levels of the trainers who received a master's degree, the trainers who received an associate's degree, and the trainers who received a high school education are higher in the sub-dimension s of avoidant attachment, anxious attachment, and secure attachment, respectively. It can be said that trainers with postgraduate education are negative towards their athletes, have difficulty in establishing closeness, hesitate to get support under stress, and do not find anyone good enough. It can be said that trainers with an associate's degree focus on negative feelings towards their athletes, cannot make a healthy assessment, and are in anxiety. It can be said that trainers with high school education are positive and optimistic and trust their athletes. Studies show that high coach-athlete communication in football has positive effects on the emotional states of football players (Abakay, 2010). It shows that the dynamics of the interaction between the coach and the athlete play a key role in the full perception of each other's thoughts and feelings (Lorimer \& Jowett, 2009). It is because the positive coach-athlete relationship also contributes to the individual and social development of athletes (Güllü, 2018).

A significant difference was found in the avoidant attachment and anxious attachment dimensions according to the duration of coaching of the participants. It is seen that this difference is between the participants who have been coaching for 1-5 years and the participants who have been coaching for 6-10 years. The high average score of the trainers with the least amount of time for coaching in the avoidant attachment and anxious attachment dimension can be thought to be due to low self-esteem, difficulty in establishing intimacy, stress and anxiety in order to achieve success, and inability to make healthy choices against athletes. It is seen that the trainers with a long coaching time have the highest average in self-confidence dimension. It can be said that these trainers are more self-confident, calmer, more empathetic, able to establish deeper relationships and more successful in communication. The positive coach-athlete relationship that takes place in an environment where positive communication processes and positive relationships are established helps athletes to bring their motivation and skill development to the desired level (Altıntaş et al., 
2012). It is stated that the higher the quality of the relationship is, the higher the sportive performance will be (Adie \& Jowett, 2010). It is known that self-confidence in the sports environment is considered a critical success factor for all levels (Machida et al., 2017). Therefore, it reveals that this factor is important for people with high self-confidence to focus on positive thoughts and to be calmer and more comfortable even under stress (Ekinci et al., 2014). In the study conducted by Abakay and Kuru (2011), it is stated that the communication levels of athletes increase as the duration of working with the trainer increases. Buğdayc1 et al. (2017), in their study with indoor football coaches, stated that an important factor in the opening of communicative channels between the coach and the athlete is the length of the coach-athlete working time. In the study conducted by Yücel (2010), it was determined that the license period did not make a significant difference in terms of the harmonious working of the trainer and the athlete.

A significant difference was found in the anxious attachment dimension according to the weekly training number of the participants. It was observed that this difference was found to be between the participants who coached for 1-5 years and 16 years or more in favor of the participants who had coached for 6-10 years and for 11-15 years in the avoidant attachment dimension. In the anxious attachment dimension, it was observed that it was among the trainers who trained 6 or more in favor of the coaches who trained 1-3 a week. It appears to be among the coaches. It shows that the trainers with a high number of trainings have clear plans for the future and establish positive and healthy relationships with their athletes who work hard for their goals and can manage their fears and anxieties well in line with their goals. Because anxious connected coaches find it difficult to accept intimacy efforts, they may not be successful despite attempts to connect. Even if their efforts to be close to their coaches are accepted by anxiously committed coaches, athletes can never be fully satisfactory (Ainsworth et al., 1978; Mikulincer \& Shaver, 2007). Coaches with an avoidant attachment style are more likely to feel that their goals are fulfilled if their needs in relation to the athlete are met (Ryan \& Deci, 2001). Davis and Jowett (2010) showed in their study that trainers who avoid attachment do not perceive the coach-athlete relationship as satisfactory. At the same time, Davis and Jowett (2010) indicated that avoidance of attachment is linked to levels of dysfunction and that levels of dysfunction can be reduced and possibly eliminated if basic needs are met. In a study conducted, it was found that there is a statistically significant difference in favor of the athletes who train more in terms of coach-athlete relationship level scores and commitment according to the weekly training time (Gönen, 2019).

Different from the current study, gender and team/individual sports variables were taken into consideration in the studies conducted (Sinnott, 2015; Lavoi, 2007) and in team sports, the levels of coach-athlete relationship were found to be higher than in individual sports (Baker et al., 2013).

The positive approach of the trainer contributes to the self-esteem of the athletes and gives the trainer respect, value, dignity and confidence. The negative approach, on the other hand, increases the athlete's fear of failure, decreases their self-esteem and causes their confidence to disappear (Konter, 2004). Therefore, individual differences and relational models of the coach have an important place in the related literature. As a result, it was seen that the 
variables of marital status, year of coaching and weekly training time significantly affect the attachment style of the trainers with their athletes. It was found that the coaches who are married, who have been working as trainers for a longer time and train 6 times or more in a week have good problem solving skills in their interpersonal relationships, have a positive approach to problems, are constructive in problem solving, are self-confident, do not evade responsibility and have an insistent attitude in solving problems. Trainers can help athletes develop their positive emotions and life satisfaction with healthy evaluations and positive/optimistic thoughts. It is thought that the sharing environment that develops as a result of the cooperation and efforts made in line with common goals in sports environments, especially in training, increases the level of coach-athlete relationship.

\section{Suggestions}

It is recommended to include information that can help trainers to establish effective relationships with their athletes in coach training programs. The results of our study can be used to develop potential interventions aimed at improving the well-being of insecure coaches.

\section{References}

Abakay, U. (2010). Futbolcu-Antrenör iletişiminin farklı statülerdeki futbolcuların başarı motivasyonuyla ilişkisi (p. 8, Doktora Tezi, Gazi Üniversitesi Sağlık Bilimleri Enstitüsü, Ankara).

Abakay, U., \& Kuru, E. (2011). Profesyonel ve Amatör Futbolcuların Antrenörleri ile Olan İletişim Düzeyi Farklı1ıklarının Karşılaştırılması. Selçuk Üniversitesi Beden Eğitimi ve Spor Bilim Dergisi, 13(1), 125-131.

Adie, J. W., \& Jowett, S. (2010). Metaperceptions of the coach-athlete relationship, achievement goals. and intrinsic motivation among sport participants. Journal of Applied Social Psychology, 40(11), 2750-2773. https://doi.org/10.1111/j.1559-1816.2010.00679.x

Ainsworth, M. D. S., Blehar, M. C., Waters, E., \& Wall, S. (1978). Patterns of attachment: Assessed in the strange situation and at home. Hillsdale, NJ: Erlbaum. https://doi.org/ 10.1002/1097-0355(198021)1:1<68:AID-IMHJ2280010110>3.0.CO;2-3

Aisworth, M. D. S. (1967). Infancy in Uganda: Patterns of Attachment Behavior. Retrieved from http://www.psychology.sunysb.edu/attachemnt/pdf/mda_uganch 20.pdf

Altıntaş, A., Çetinkalp, Z., \& Aşçı, H. (2012). Antrenör-sporcu ilişkisinin değerlendirilmesi: Geçerlik ve güvenirlik çalışması. Spor Bilimleri Dergisi, 23(3), 119-128.

Arslan, E., Arslan, C., \& Arı, R. (2012). Kişiler arası problem çözme yaklaşımlarının, bağlanma stilleri açısından incelenmesi. Kuram ve Uygulamalı Eğitim Bilimleri, 12, 1-14.

Baker, J., Yardley, J., \& Côté, J. (2003). Coach behaviors and athlete satisfaction in team and individual sports. International Journal of Sport and Exercise Psychology, 34, 226-239.

Bartholomew, K. J., Ntoumanis, N., \& Thøgersen-Ntoumani, C. (2010). The controlling 
interpersonal style in a coaching context: development and initial validation of a psychometric scale. Journal of Sport and Exercise Psychology, 32, 193-216. https://doi.org/ 10.1123/jsep.32.2.193

Baysal, A., \& Özgenel, M. (2019). Ortaokul Öğrencilerinin Bağlanma Stilleri ve Öz-Düzenleme Düzeyleri Arasındaki İlişkinin İncelenmesi, Eğitimde Kuram ve Uygulama, 15(2), 142-152. https://doi.org/10.17244/eku.507650

Blanchard, C. M., Amiot, C. E., Perreault, S., Vallerand, R. J., \& Provencher, P. (2009). Cohesiveness, coach's interpersonal style and psychological needs: their effects on self-determination and athletes' subjective well-being. Psychology of Sport and Exercise, 10, 546-551. https://doi.org/10.1016/j.psychsport.2009.02.005

Bowlby, J. (1973). Attachment and Loss: Vol. 2. Separation: anxiety and anger. New York, NY: Basic Books.

Bowlby, J. (1980). Attachment and Loss: Vol. 3. Loss. New York: Random House.

Bowlby, J. (1982). Attachment and Loss: Vol. 1. Attachment. New York: Basic Books.

Buğdaycı, S., Zengin, Ö., Abakay, U., \& Demir, H. (2017). Leadership styles of futsal coaches from athletes' perceptions. Turkish Journal of Sport and Exercise, 19(3), 354-359. https://doi.org/10.15314/tsed.313481

Büyüköztürk, Ş., Kılıç Çakmak, E., Akgün, Ö. E., Karadeniz, Ş., \& Demirel, F. (2012). Bilimsel Araştırma Yöntemleri. Ankara: Pegem Akademi.

Chen, W., Zhang, D., Pan, Y., Hu, T., Liu, G., \& Luo, S. (2017). Perceived social support and self-esteem as mediators of the relationship between parental attachment and life satisfaction among Chinese adolescents. Personal. Individ. Dier., 108, 98-102. https://doi.org/10.1016/ j.paid.2016.12.009

Côté, J., \& Fraser-Thomas, J. (2007). Youth involvement in sport. In P. R. E. Crocker (Ed.), Introduction to sport psychology: A Canadian perspective (pp. 266-294). Toronto: Pearson Prentice Hall.

Davis, L., \& Jowett, S. (2010). Investigating the interpersonal dynamics between coaches and athletes based on fundamental principles of attachment. Journal of Clinical Sport Psychology, 4, 112-132. https://doi.org/10.1123/jcsp.4.2.112

Davis, L., \& Jowett, S. (2011). Passion for coaching and the quality of the coach-athlete relationship: The mediating role of coaching behaviors. Psychology of Sport and Exercise, 12(2), 144-152. https://doi.org/10.1016/j.psychsport.2010.08.002

Demir, D. S. (2019). Yetişkinlerde bağlanma stilleri ile sürekli kaygl düzeyi ve sosyotropik-otonomik kişilik özellikleri arasındaki ilişkinin incelenmesi (Yüksek Lisans Tezi, Iş1k Üniversitesi).

Ekinci, N. E., Özdilek, Ç., Deryahanoğlu, G., \& Üstün, Ü. D. (2014). Spor yapan lise öğrencilerinin öz güven düzeylerinin incelenmesi, Sportif Bakış: Spor ve Eğitim Bilimleri 
Dergisi, 1(1), 36-42.

Gönen, M. (2019). Antrenör-Sporcu İlişkisinin Sporcuların Durumluk Kaygl, Öfke ve Öznel Iyi Oluş Düzeylerine Etkisi: Taekwondo ve Korumalı Futbol Örneği (Doktora Tezi, Sağlık Bilimleri Enstitüsü, Gazi Üniversitesi, Ankara).

Güllü, S. (2018). Sporcuların antrenör-sporcu ilişkisi ile sportmenlik yönelimleri üzerine bir araştırma. Spormetre Beden Eğitimi ve Spor Bilimleri Dergisi, 16(4), 190-204.

Jowett, S., \& Cockerill, I. M. (2003). Olympic medallists, perspektive of the athlete- coach relationship, Psychology of Spot and Exercise, 4, 313-331. https://doi.org/10.1016/S14690292(02)00011-0

Karakuş, Ö. (2012). Ergenlerde bağlanma stilleri ve yalnızlık arasındaki ilişki. Journal of Society \& Social Work, 23(2).

Koser, İ., \& Barut, Y. (2020). Üniversite Öğrencilerinin İletişim Becerileri, Problem Çözme Becerileri ve Bağlanma Stilleri İlişkisi. OPUS Uluslararası Toplum Araştırmaları Dergisi, 15(23), 1765-1789. https://doi.org/10.26466/opus.622867

Lavoi, N. M. (2007). Expanding the interpersonal dimension: Closeness in the coach-athlete relationship. International Journal of Sports Science and Coaching, 2(4), 497-512. https://doi.org/10.1260/174795407783359696

Lee, A., \& Hankin, B. L. (2009). Insecure attachment, dysfunctional attitudes, and low self-esteem predicting prospective symptoms of depression and anxiety during adolescence. $J$. Clin. Child Adolesc. Psychol., 38, 219-231. https://doi.org/10.1080/15374410802698396

Lorimer, R., \& Jowett, S. (2009). Empathic accuracy in coach-athlete dyads who participate in team and individual sports. Psychology of Sport and Exercise, 10(1), 152-158. https://doi.org/10.1016/j.psychsport.2008.06.004

Machida, M., Otten, M., Magyar, T. M., Vealey, R. S., \& Ward, R. M. (2017). Examining multidimensional sport-confidence in athletes and non-athlete sport performer. Journal of Sports Sciences, 35(5), 410-418. https://doi.org/10.1080/02640414.2016.1167934

Mageau, G. A., \& Vallerand, R. J. (2003). The coach-athlete relationship: a motivational model. Journal of Sport Sciences, 21, 883-904. https://doi.org/10.1080/026404103100 0140374

Mallinckrodt, B., \& Wei, M. (2005). Attachment, social competencies, social support, and psychological distress. J. Couns. Psychol., 52, 358. https://doi.org/10.1037/0022-0167. 52.3.358

Mikulincer, M., \& Shaver, P. R. (2007). Attachment in adulthood: Structure, dynamics, and change. New York: Guilford Press.

Reinboth, M., Duda, J. L., \& Ntoumanis, N. (2004). Dimensions of coaching behaviour, need satisfaction, and the psychological and physical welfare of young athletes. Motivation and Emotions, 28, 297-313. https://doi.org/10.1023/B:MOEM.0000040156.81924.b8 


\section{Macrothink}

Ryan, R. M., \& Deci, E. L. (2001). On happiness and human potentials: A review of research on hedonic and eudaimonic well-being. Annual Review of Psychology, 52, 141-167. https://doi.org/10.1146/annurev.psych.52.1.141

Sinnott, C. (2015). Exploring the factors that impact on the quality of coach-athlete relationship (p. 32, Degree of Bachelor of Science, Cardiff Metropolitan University).

Smoll, F. J., \& Smith, R. E. (1989). Leadership behaviours in sport: A theoretical model of research paradigm. Journal of Applied Social Psychology, 19, 1522-1551. https://doi.org/ 10.1111/j.1559-1816.1989.tb01462.x

Tabachnick, B. G., \& Fidell, L. S. (2013). Using Multivariate Statistics (6th ed.). Northridge. CA: California State University.

Ürkmez, G. (2008). Spor ve Başart. Retrieved from https://www.tavsiyeediyorum.com/ makale 2121.htm

Verschueren, K. (2020). Attachment, self-esteem, and socio-emotional adjustment: There is more than just the mother. Attach. Hum. Dev., 22, 105-109. https://doi.org/10.1080/14616734. 2019.1589066

Yiğit, Y. (2020). Lise öğrencilerinde bağlanma stilleri ile öz-yeterlik arasındaki ilişkinin incelenmesi (Maltepe Üniversitesi, Lisansüstü Eğitim Enstitüsü, İstanbul).

Yıldırım, S., Yıldız, A., \& Koruç, Z. (2019). Mücadele Sporlarında Antrenör Sporcu İlişkileri ve Liderliğin Yaş, Cinsiyet ve Katılım Süresi Değişkenleri Açısından İncelenmesi. Niğde Üniversitesi Beden Eğitimi ve Spor Bilimleri Dergisi, 13(1).

Yücel, M. G. (2010). Antrenör-sporcu ilişkisini etkileyen faktörler (güreş örneği) (p. 63, Yüksek Lisans Tezi, Gazi Üniversitesi, Ankara).

Zengin, Ö. (2019). Antrenör-Sporcu arasındaki ilişkilerde bağlanma stilleri ölçeğinin geçerlik ve güvenirlik çalışması (Doktora Tezi, Selçuk Üniversitesi Sağlık Bilimleri Enstitüsü).

\section{Copyright Disclaimer}

Copyright for this article is retained by the author(s), with first publication rights granted to the journal.

This is an open-access article distributed under the terms and conditions of the Creative Commons Attribution license (http://creativecommons.org/licenses/by/3.0/). 